\title{
Feeding habits of coypu (Myocastor coypus Molina 1978) in the wetlands of the Southern region of Brazil
}

\author{
IONI G. COLARES ${ }^{1,2}$, RAQUEL N. V. OLIVEIRA ${ }^{3}$, RAFAEL M. OLIVEIRA ${ }^{4}$ \\ and ELTON P. COLARES ${ }^{1,2,3}$ \\ ${ }^{1}$ Instituto de Ciências Biológicas, Universidade Federal do Rio Grande-FURG \\ Av. Itália, km 8, Campus Carreiros, 96201-900 Rio Grande, RS, Brasil \\ ${ }^{2}$ Programa de Pós-Graduação em Biologia de Ambientes Aquáticos Continentais \\ Universidade Federal do Rio Grande-FURG, Av. Itália, km 8, Campus Carreiros, 96201-900 Rio Grande, RS, Brasil \\ ${ }^{3}$ Programa de Pós-Graduação em Ciências Fisiológicas: Fisiologia Animal Comparada, Universidade Federal do Rio Grande-FURG \\ Av. Itália, km 8, Campus Carreiros, 96201-900 Rio Grande, RS, Brasil \\ ${ }^{4}$ Especialização em Ecologia Aquática Costeira, Universidade Federal do Rio Grande-FURG \\ Av. Itália, km 8, Campus Carreiros, 96201-900 Rio Grande, RS, Brasil \\ Manuscript received on June 23, 2008; accepted for publication on April 12, 2010
}

\begin{abstract}
The aim of this study was to determine the diet of coypu (Myocastor coypus) in two areas (Santa Isabel do Sul wetlands - Area 1, and Santa Marta Farm - Area 2) in the Southern region of Brazil, using microhistological analyses of feces. Twenty-four plant species were identified from collected feces samples. Among the identified species, nine are common in the animals' diet in both areas; the presence of Oriza sativa was not detected in any of the samples. Among the identified species, $84 \%$ and $54 \%$ of the coypu's diet from Areas 1 and 2, respectively, are aquatic plants. Poaceae family was most common, being found in $82 \%$ of the samples from both areas. Paspalum disthichum (Area 1) and Panicum tricholaenoides (Area 2) were the most frequent species on the coypu's diet. The diet comparison for both areas indicates that feeding habits vary depending on the type of habitat, environmental conditions and food availability. The absence of rice in our analysis may be an indication for the preservation of native areas around watercourses, so as to prevent coypu from invading irrigated crops.
\end{abstract}

Key words: coypu, diet, food selection, herbivore.

\section{INTRODUCTION}

In general, wild herbivores use different strategies in their diet selection according to food quality and abundance, the habitat, and the morphology and physiology of the animal (Galende and Gricera 1998). Basic studies about the diet of wild herbivores may be developed from direct observation of the animals (Barreto and Herrera 1998, Prigioni et al. 2005), analysis of the composition of stomach content samples (Quintana et al. 1994), or by using microhistological analysis of feces

Correspondence to: Ioni Gonçalves Colares

E-mail: dmbioni@furg.br
(Abbas 1991). The main advantages in the use of feces in this type of study are the unlimited number of samples and the non-interference in the animal habits (Quintana et al. 1994).

The study of alimentary habits using microhistological analysis of feces was originally developed by Baumgartner and Martin (1939) with squirrels. Since then, it has been used by many authors with different species of herbivores, including aquatic herbivores, like the Amazon manatee (Colares and Colares 2002), and semi-aquatic ones, like the capybara (Borges and Colares 2007). Studies of coypus' alimentary habits have been done in Argentina (Borgnia et al. 2000, D'adamo 
et al. 2000, Guichón et al. 2003), France (Abbas 1988, 1991), and Italy (Prigioni et al. 2005).

The coypu (Myocastor coypus) is an indigenous semi-aquatic herbivorous rodent native from the south of South America, living near watercourses (Borgnia et al. 2000). This species has a status of population declining within its native range (IUCN 2009). The species was introduced in North America, Europe, Middle East, Africa and Japan, living in the same habitat (Abbas 1991, D'adamo et al. 2000). In some of these regions, the coypu is an exotic animal; it causes damage to crops, native flora and fauna, and drainage systems (Abbas 1988, Borgnia et al. 2000, Guichón et al. 2003). They are herbivores with nocturnal habits, with high foraging activity near burrow exits, where they feed on grasses, roots and aquatic plants (Abbas 1988, 1991, Borgnia et al. 2000). They restrict their foraging activities to the surroundings of watercourses with the purpose of reducing energetic waste in escapes from possible predators (D'adamo et al. 2000). Their feces are cylindrical, prolonged and in green tones, being easily found floating on watercourse edges as well as on land.

Although the coypu is cited as a threat to cereal plantations, not only in the places where they were introduced, but also in their natural habitat, there are few studies that try to evaluate the real impact of the herbivores to cereal plantations (Borgnia et al. 2000). Being rodents of large occurrence in flooded areas in the state of Rio Grande do Sul - these areas being used for the culture of cereals, especially irrigated rice - it became essential to carry out studies about the coypu's alimentary habits and the possible ingestion of cultured vegetables. As a result, the objective of this study was to determine the composition of the diet and the seasonal changes in the food consumed by the coypus (M. coypus), as well as to investigate the interference of the species in rice (Oriza sativa L.) fields.

\section{MATERIALS AND METHODS}

\section{STUDy AREA}

The study took place on the Southern region of the state of Rio Grande do Sul, Brazil, in two areas, $75 \mathrm{~km}$ apart from each other. The climate of this region is temperate, with annual precipitation average of around $1,100 \mathrm{~mm}$ and average temperature of $18^{\circ} \mathrm{C}$ (Nogueira-Neto 1993). Area 1 includes Santa Isabel do Sul wetlands, located in the city of Rio Grande $\left(32^{\circ} 06^{\prime} 56^{\prime \prime}\right.$ South latitude and $52^{\circ} 35^{\prime} 58^{\prime \prime}$ West longitude). Across the wetlands, there is a $14-\mathrm{km}$ road surrounded by two channels for irrigation of rice cultures. Area 2 includes the Santa Marta Farm, a private rural property whose main activity is the culture of irrigated rice. It is located in the city of Santa Vitória do Palmar $\left(32^{\circ} 50^{\prime} 41.10^{\prime \prime}\right.$ South latitude and $52^{\circ} 39^{\prime} 04.77^{\prime \prime}$ West longitude). It is surrounded by an artificial channel built for irrigation, limited by rice culture on one side and by native vegetation on the other.

\section{Feces Collection}

The collection of recent coypu feces was conducted monthly, during the period between December 2003 and November 2004 at Area 1, and between July 2005 and June 2006 at Area 2. During the field research, both edges of the channels and the surroundings of the floodable areas were covered on foot. Thirty-six samples were collected from Area 1, and 46 samples from Area 2. The feces samples were conserved in FAA (85\% alcohol, $10 \%$ formalin at $10 \%$, and $5 \%$ glacial acetic acid) for subsequent fecal analysis.

\section{FeCAl Analysis}

The fecal analysis consists in a comparison between fragments of the vegetal epidermis found in the feces of the animals with epidermal layers of previously identified plants, mounted as a photomicrographic reference collection (Storr 1961). The reference collection used in this study belongs to the Botanics Laboratory of the Biological Sciences Institute (ICB) of Universidade Federal do Rio Grande (FURG). From the samples conserved in FAA, three sub-samples were taken, from which five microscope slides were prepared and analyzed based on Abbas (1991). These slides were analyzed in all their extension, noting down the type of material found and the number of relapses. For the identification of species, its anatomical characteristics, such as size, shape and types of epidermis cells, presence and distribution of silica incrustations, distribution and type of stomata, presence and type of trichomes or solid inclusions were considered. 


\section{DATA TREATMENT}

The data were grouped to determine the vegetal species consumed by the coypus, from both areas under study, taking seasonal variation into account. The frequency of each alimentary item was calculated according to the formula $\mathrm{A} \%=$ (number of fragments of item $\mathrm{i} / \mathrm{number}$ of fragments observed) $\times 100$ (Abbas 1991). Diet diversity was calculated with the Shannon index (Schäfer 1980), followed by the Hutchinson test $(\mathrm{p}<0.05)$ (Zar 1984), to define the significance of differences in resource utilization, independently from its availability.

\section{RESULTS}

From the collected feces samples, 24 plant species belonging to six families and 10 plant species belonging to five families were identified from Areas 1 and 2, respectively (Table I). Among the identified species, nine are common in the animals' diet from both areas, not being detected the presence of Oriza sativa in any of the samples.

Seasonally, in Area 1, the diversity of plants by feces sample ranged between 10 species in spring and 14 in winter, with 16 species in the summer and autumn (Table II). The Shannon diversity index was higher in autumn $(\mathrm{H}=4.28)$, with similarity during the rainy seasons (winter and spring) and significant differences $(\mathrm{p}<0.05)$ in diet during others seasons (Table III).

In Area 2, two species were identified in the summer and nine in the winter, with six species in the spring and eight in the autumn (Table II). The Shannon diversity index was higher in the winter $(\mathrm{H}=1.95)$, with significant differences $(\mathrm{p}<0.05)$ in diet diversity among the seasons (Table III). Between both study areas, the composition of the coypu's diet presented significant differences $(p<0.05)$ in all seasons.

From the identified species, $84 \%$ and $54 \%$ of the coypu's diet from Areas 1 and 2, respectively, are aquatic plants. The Poaceae family was most common, being found in $82 \%$ of the samples from both Areas. Paspalum disthichum (Area 1) and Panicum tricholaenoides (Area 2) were the most frequent species in coypu's diet (Table I and II). Despite the incidence of dicotyledons at the study areas, the monocotyledons were the coypu's preference (86\%), with the species Ecliptra pros- trata (Asteraceae family) being the most consumed in the summer (18.6\%) at Area 1 (Table II)

\section{DISCUSSION}

To herbivores, in general, seasonal variations in food quantity and quality may have an important effect on the development of the species (Bronson 1989). In France and Argentina, studies of the alimentary habits of coypus showed a diet that constituted of 40 species (Abbas 1991), and 31 species (Borgnia et al. 2000), respectively, while, in Italy, 24 species were identified (Prigioni et al. 2005). According to Prigioni et al. (2005), the diet selection by coypus ranges seasonally according to the environmental characteristics and peculiarities of each region. The number of species identified in this study was lower, with specific differences between both areas possibly related to the physiognomic characteristics of them. Area 1 is mainly constituted of marshes occupied by native vegetation, while Area 2 is characterized by agricultural crops, with reduced occupation of native vegetation. Thus, the micro-habitat occupation, the variations in the abundance, energy content and food distribution relative to the distance from the water may be controlling the differentiated search of alimentary items by the coypus.

Besides the variations in food supply, the ones in nutritional content are also observed as a function of the place and time of the year (Best 1981). The nutritional quality and digestibility of the plants are critical to herbivores, the young leaves being frequently preferred for the lower presence of cellulose (Ricklefs 2003). Although the spring is the season with the greatest availability of plants (personal observation), the number of species consumed by the coypus, at Area 1, was smaller. This season corresponds to the ending of the overflow period and is characterized by presenting vegetation in growth phase, with the emergence of more palatable sprouts and soft leaves with better proteic and lipidic quality. Due to the greater food availability, the coypus begins to show a more selective behavior, consuming big quantities of a smaller number of species of their preference.

In general, during dry seasons, herbivores, faced with food scarcity, present an opportunistic behavior, ingesting the available food regardless of its nutritional quality (Kufner and Monge 1998). The kind of food 
TABLE I

Species of plants identified in coypu's feces (Myocastor coypus) from both areas

(Area 1 - Santa Isabel do Sul wetlands; Area 2 - Santa Marta Farm), its habit and percentage of annual occurrence. $\mathrm{A}=$ amphibious, $\mathrm{E}=$ emergent, $\mathrm{FF}=$ floating fasten, $\mathrm{FL}=$ floating free, $\mathrm{S}=\operatorname{submersed}$ and $\mathrm{T}=$ terrestrial.

\begin{tabular}{|c|c|c|c|c|}
\hline Family & Species & $\begin{array}{l}\text { Plant } \\
\text { habits }\end{array}$ & $\begin{array}{c}\% \text { of } \\
\text { occurrence } \\
\text { Area } 1\end{array}$ & $\begin{array}{c}\% \text { of } \\
\text { occurrence } \\
\text { Area } 2\end{array}$ \\
\hline Asteraceae & Baccharis articulata (Lam) Pres & $\mathrm{T}$ & 0.1 & 0 \\
\hline Asteraceae & Baccharis trimera (Less.) DC & $\mathrm{T}$ & 0.1 & 0 \\
\hline Asteraceae & Bidens laevis (L.) BSP & $\mathrm{FF} / \mathrm{A} / \mathrm{E}$ & 1.0 & 0 \\
\hline Asteraceae & dicotiledons not identified & A & 3.5 & 0 \\
\hline Asteraceae & Ecliptra prostrata $\mathrm{L}$. & $\mathrm{A} / \mathrm{E}$ & 9.1 & 0.9 \\
\hline Cyperaceae & Cyperus ferax L.C. Rich & $\mathrm{A} / \mathrm{E}$ & 0.2 & 0 \\
\hline Cyperaceae & Cyperus luzulae (L.) Retz & A & 0.2 & 0 \\
\hline Cyperaceae & Cyperus polystachios Rottb. & $\mathrm{T}$ & 1.2 & 0 \\
\hline Cyperaceae & Cyperus sp. L. & A & 0 & 3.1 \\
\hline Oenotheraceae & Epilobium angustifolium L. & $\mathrm{T}$ & 0 & 13.3 \\
\hline Poaceae & Cynodon dactylon (L.) Persoon & $\mathrm{T}$ & 1.7 & 0 \\
\hline Poaceae & Echinochloa polystachia Hitchc. & $\mathrm{A} / \mathrm{E}$ & 3.6 & 1.3 \\
\hline Poaceae & Echinochloa sp. Hitchc. & $\mathrm{A} / \mathrm{E}$ & 0.3 & 0 \\
\hline Poaceae & Eragrostis hypnoides (Lam) Briflon & A & 0.3 & 0 \\
\hline Poaceae & Panicum elephantipes Ness & $\mathrm{FF} / \mathrm{A} / \mathrm{E}$ & 10.1 & 31.6 \\
\hline Poaceae & Panicum repens $\mathrm{L}$. & A & 2.4 & 0 \\
\hline Poaceae & Panicum tricholaenoides Steudel & $\mathrm{T}$ & 8.1 & 32.5 \\
\hline Poaceae & Paspalidium paludivagum (Hitchok et Chase) Par & $\mathrm{FF} / \mathrm{S} / \mathrm{A}$ & 2.1 & 6.7 \\
\hline Poaceae & Paspalum disthichum $\mathrm{L}$. & A & 22.3 & 0 \\
\hline Poaceae & Paspalum urvillei Stendel & $\mathrm{T}$ & 1.4 & 0 \\
\hline Poaceae & Polypogon chilensis (Kunth) Pilger & $\mathrm{T}$ & 4.7 & 0.2 \\
\hline Poaceae & Setaria geniculata (Lam) Beauvois & $\mathrm{T}$ & 6.9 & 0 \\
\hline Poaceae & Zizaniopsis bonariensis (Bal. et Poitr.) Spegazzini & $\mathrm{E}$ & 18.3 & 10.2 \\
\hline Polygonaceae & Polygnum punctatum Elliot & A / S & 0.4 & 0.2 \\
\hline Pontederiaceae & Eichhornia crassipes (Mart.) Solms-Laubach & FL & 2.1 & 0 \\
\hline Verbenaceae & Phyla nodiflora (H.B.K.) Moldenk & $\mathrm{T}$ & 0.1 & 0 \\
\hline
\end{tabular}

ingested is not an important factor in the coypu's diet as it has specific digestive strategies, taking the maximum advantage from the nutrients of the ingested plant (Sakaguchi and Nabata 1992). During the summer and autumn, a reduction at the overflow level and the supply of succulent plants is observed, which makes a considerable raise in the number of species (16) consumed by the coypus at in this experiment. Lots of these plants were with very low occurrence (Table II), which suggests a search, among the available plants, for more palatable species.

On the other hand, at Area 2, despite the seasonal drought, summer was the season with the smallest num- ber of ingested species ( 2 species). It was observed that the artificial rice irrigation channels are kept full during the period of seasonal drought. Therefore, water is available, consequently favoring the native vegetation by keeping the leaves succulent and palatable. In the presence of a more nutritive food item, the coypu has a more selective behavior, ingesting a smaller number of alimentary items.

The ingestion of aquatic plants by the coypus, besides being a great source of nutrients, prevents energetic costs associated with others behaviors, like the escape from predators (Guichón et al. 2003). The consumption of aquatic plants by the coypus is advantageous, once it 
TABLE II

(A) Species of plants identified in coypu's diet (Myocastor coypus) and percentage of contribution from each alimentary item in different seasons of the year. (B) Seasonal diversity of diet ( $\mathrm{H}^{\prime}$ ' = Shannon's Diversity Index). Area 1 - Santa Isabel do Sul wetlands; Area 2 - Santa Marta Farm.

\begin{tabular}{|c|c|c|c|c|c|c|c|c|}
\hline \multirow{2}{*}{ A) Species } & \multicolumn{2}{|c|}{ Summer $(\%)$} & \multicolumn{2}{|c|}{ Autumn (\%) } & \multicolumn{2}{|c|}{ Winter $(\%)$} & \multicolumn{2}{|c|}{ Spring (\%) } \\
\hline & Area 1 & Area 2 & Area 1 & Area 2 & Area 1 & Area 2 & Area 1 & Area 2 \\
\hline Baccharis articulata & 0 & 0 & 0.5 & 0 & 0 & 0 & 0 & 0 \\
\hline Baccharis trimera & 0 & 0 & 0.6 & 0 & 0 & 0 & 0 & 0 \\
\hline Bidens laevis & 0 & 0 & 0 & 0 & 0 & 0 & 3.6 & 0 \\
\hline Cynodon dactylon & 0 & 0 & 0 & 0 & 4.7 & 0 & 2.6 & 0 \\
\hline Cyperus ferax & 0.5 & 0 & 0 & 0 & 0 & 0 & 0 & 0 \\
\hline Cyperus luzulae & 0.6 & 0 & 0 & 0 & 0 & 0 & 0 & 0 \\
\hline Cyperus polystachios & 0 & 0 & 0 & 0 & 0 & 0 & 4.2 & 0 \\
\hline Cyperus sp. & 0 & 0 & 0 & 2.7 & 0 & 1.6 & 0 & 4.8 \\
\hline Dicotiledonea & 8.5 & 0 & 3.7 & 0 & 0.6 & 0,0 & 0 & 0 \\
\hline Echinochloa polystachia & 2.5 & 0 & 4.6 & 0.7 & 3.3 & 3.3 & 4.3 & 0 \\
\hline Echinochloa sp. & 0.8 & 0 & 0 & 0 & 0 & 0 & 0 & 0 \\
\hline Ecliptra prostrata & 18.6 & 0 & 16.3 & 0.7 & 0 & 2.2 & 0 & 0 \\
\hline Eichhornia crassipes & 0 & 0 & 0.8 & 0 & 9.1 & 0 & 0 & 0 \\
\hline Eragrostis hypnoides & 0.4 & 0 & 0.7 & 0 & 0 & 0 & 0 & 0 \\
\hline Epilobium angustifolium & 0 & 0 & 0 & 0 & 0 & 17.6 & 0 & 19.8 \\
\hline Panicum elephantipes & 11.2 & 63.6 & 17.9 & 48.6 & 6.9 & 19.8 & 5.5 & 28.1 \\
\hline Panicum repens & 6.1 & 0 & 0.7 & 0 & 1.9 & 0 & 0 & 0 \\
\hline Panicum tricholaenoides & 9.9 & 36.4 & 2.5 & 37.8 & 0 & 32.9 & 16.0 & 28.1 \\
\hline Paspalidium paludivagum & 1.7 & 0 & 2.3 & 2.0 & 4.8 & 14.8 & 0 & 3.4 \\
\hline Paspalum disthichum & 9.2 & 0 & 12.7 & 0 & 45.3 & 0 & 26.4 & 0 \\
\hline Paspalum urvillei & 4.6 & 0 & 0 & 0 & 0.1 & 0 & 0 & 0 \\
\hline Phyla nodiflora & 0 & 0 & 0 & 0 & 0.4 & 0 & 0 & 0 \\
\hline Polygnum punctatum & 0 & 0 & 0.7 & 0.7 & 1.4 & 0 & 0 & 0 \\
\hline Polypogon chilensis & 3.8 & 0 & 3.2 & 0 & 5.9 & 0.6 & 5.7 & 0 \\
\hline Setaria geniculata & 9.7 & 0 & 4.7 & 0 & 1.3 & 7.1 & 9.8 & 15.9 \\
\hline Zizaniopsis bonariensis & 11.9 & 0 & 27.8 & 6.8 & 13.9 & 0 & 21.7 & 0 \\
\hline B) $\mathrm{H}^{\prime}$ & 3.6 & 0.5 & 4.3 & 1.1 & 3.0 & 1.9 & 3.1 & 1.5 \\
\hline
\end{tabular}

has digestive mechanisms that is suitable for the ingestion of these plants (Guichón et al. 2003). The higher consumption of aquatic vegetation, as observed in this study, is related to the type of environment in which this species occurs, where the foraging of aquatic plants is represented more as a process of habitat selection than of food choice. Besides, the adaptation of the coypus to the aquatic environment allows for the use of an advantageous alimentary supply, since most of aquatic plants lack alkaloids, tannin and lignin (Lebreton 1982).

In general, the consumption of terrestrial vegetation by the coypus has been observed only when aquatic vegetation is scarce (Abbas 1991, Guichón et al. 2003, Prigioni et al. 2005). Young individuals of coypus use terrestrial vegetation in their diet as an integrative resource, fulfilling their nutritional requirements with lower energy investment (Prigioni et al. 2005). Since Area 2 is characterized as an agricultural region, with a smaller rate of overflow, the supply of aquatic vegetation is reduced, increasing the search for terrestrial vegetation by the animals. This was especially observed in the winter, possibly favored by a scarcity of aquatic vegetation, lack of natural predators and a reduction in the movement of machines and people working on rice 
TABLE III

Values of the Hutchinson test, at 5\% significance, among the seasonal diversity indexes of coypu's diet (Myocastor coypus) from both areas. $t=$ test $t ; d f=$ degrees of freedom.

A) Area 1 - Santa Isabel do Sul wetlands; B) Area 2 - Santa Marta Farm; C) Comparison between both areas.

\begin{tabular}{|c|c|c|c|c|c|}
\hline \multicolumn{6}{|l|}{ A) } \\
\hline Comparison & $\mathrm{t}$ & $\mathrm{df}$ & $t^{\prime}$ & $\mathrm{p}$ & Result \\
\hline Summer - Spring & 6.873 & 265 & 1.969 & $<0.05$ & Different diversity \\
\hline Summer - Autumn & 7.394 & 240 & 1.972 & $<0.05$ & Different diversity \\
\hline Summer - Winter & 6.865 & 240 & 1.972 & $<0.05$ & Different diversity \\
\hline Autumn - Winter & 12.271 & 269 & 1.969 & $<0.05$ & Different diversity \\
\hline Autumn - Spring & 12.732 & 257 & 1.969 & $<0.05$ & Different diversity \\
\hline Winter - Spring & 0.872 & 256 & 1.969 & $>0.05$ & Similar diversity \\
\hline \multicolumn{6}{|l|}{ В) } \\
\hline Comparison & $\mathrm{t}$ & $\mathrm{df}$ & $t^{\prime}$ & $\mathrm{p}$ & Result \\
\hline Summer - Spring & 1.188 & 72 & 1.993 & $>0.05$ & Similar diversity \\
\hline Summer - Autumn & 2.189 & 41 & 2.020 & $<0.05$ & Different diversity \\
\hline Summer - Winter & 5.777 & 30 & 2.042 & $<0.05$ & Different diversity \\
\hline Autumn - Winter & 2.949 & 155 & 1.976 & $<0.05$ & Different diversity \\
\hline Autumn - Spring & 0.442 & 76 & 1.992 & $>0.05$ & Similar diversity \\
\hline Winter - Spring & 0.556 & 73 & 1.993 & $>0.05$ & Similar diversity \\
\hline \multicolumn{6}{|l|}{ C) } \\
\hline Comparison & $\mathrm{t}$ & $\mathrm{df}$ & $\mathrm{t}^{\prime}$ & $\mathrm{p}$ & Result \\
\hline Summer 1 - Summer 2 & 19.845 & 10 & 2.228 & $<0.05$ & Different diversity \\
\hline Autumn 1 - Autumn 2 & 21.578 & 129 & 1.978 & $<0.05$ & Different diversity \\
\hline Spring $1-$ Spring 2 & 5.708 & 10 & 2.201 & $<0.05$ & Different diversity \\
\hline Winter 1 - Winter 2 & 15.495 & 1 & 12.706 & $<0.05$ & Different diversity \\
\hline
\end{tabular}

*Area 1: summer 1, autumn 1, spring 1, winter 1. *Area 2: summer 2, autumn 2, spring 2, winter 2.

fields. However, at Area 1, the ingestion of terrestrial plants was low, being accentuated in the spring $(24 \%)$, when the vegetation is succulent and emits new sprouts (Table II).

Studies in France, where the coypus was introduced (Abbas 1991), and in Argentina, where it is native (Borgnia et al. 2000), observed a high frequency of species of Poaceae in its diet. At our both study areas, there was also a predominance of Poaceae species at the coypu's diet. Plant consumption of this family is associated to the availability and nutritional quality of this vegetation. According to Abbas (1991), the nutritional value and the permanent availability of Poaceae are responsible for the coypu's preference, which also probably occurs with the animals from both areas in this study.

In general, the consumption of Poaceae species by the herbivores occurs during the growth season, a period with larger energy content (McIlroy 1964). According to this author, the species in this family responded to moderate pasture with growth of new nutritious sprouts. Thus, the foraging activity by the coypus is supposed to be guaranteeing the maintenance of a soft and high energetic quality vegetation. According to Abbas (1991), during the flowering of Poaceae, an increase in tannin content and fibers in the leaves is observed, decreasing its digestibility and reducing its consumption by herbivores. The reduction in the ingestion of $P$. disthichum in the summer and $P$. tricholaenoides in the spring probably happened due to the reduction of the protein value of the current leaves during the flowering period, making the coypus ingest other plant species.

The selection of monocotyledon foraging appears to be a common model among rodents, being observed, for example, in cavia (Microcavia australis) and tucotuco (Ctenomys eremophilus) in Argentina (Borruel et 
al. 1998), and capybaras (Hydrochaeris hydrochaeris) at Taim wetlands (Borges and Colares 2007). In Argentina, Borgnia et al. (2000) also observed a preference for monocotyledons by the coypus, attributing this fact to the presence of secondary metabolites in dicotyledons, which reduces its nutritional value. In this study, the consumption of dicotyledons was restricted to the dry months of summer and autumn, probably related to the low nutritional quality offered by forage grass during this period.

In areas where the native vegetation becomes scarce due to deforestation, the coypus may focus its feeding on the closest plantations (D'adamo et al. 2000). On the other hand, in places where the native vegetation is preserved, forming belts along the length of watercourses, the coypus does not represent a threat to the cereal plantations (Borgnia et al. 2000, Guichón et al. 2003). Although the south region of the state of Rio Grande do $\mathrm{Sul}$ is characterized by vast fields, marshes and irrigation channels for rice plantations, occupied by coypu's populations, Oriza sativa was not identified in their diet in both study areas. At Area 1, the rice plantations were 100 meters from the watercourse, while at Area 2, they were 10 meters front it, with the presence of native vegetation in this interval. Considering that the average range of the coypus may reach $2 \mathrm{~km}$ (Palomares et al. 1994), the absence of rice in our analysis may be an indicative that the native vegetation caters for the nutritional needs of these populations. Therefore, the preservation of native areas around watercourses is suggested, mainly in areas next to crop plantations, so as to prevent the coypu, when faced with food scarcity, from becoming a potential pest to agriculture.

In conclusion, the results of this study suggest a diet composed of aquatic plants, predominantly of the Poaceae family, and a differentiated behavior for food selection by the coypu. The comparison of its diet from both study areas (Santa Isabel do Sul wetlands and Santa Marta Farm) indicates that its feeding habits vary depending on the type of habitat, environmental conditions and alimentary availability. In overflow periods, faced with a greater plant availability, it presents a more selective behavior, consuming a smaller number of species, probably the more palatable and nutritious ones. On the other hand, in periods of drought, when the vegetation sup- ply or quality is reduced the number of ingested species raises, as to fulfill its nutritional requirements.

\section{ACKNOWLEDGMENTS}

The authors thank the Instituto de Ciências Biológicas (ICB) of Universidade Federal do Rio Grande (FURG), for the readiness of the resources used in the execution of this work.

\section{RESUMO}

O objetivo deste estudo foi determinar a dieta do ratão-dobanhado (Myocastor coypus), em duas regiões (áreas alagadas em Santa Isabel do Sul - Área 1 e Fazenda Santa Marta Área 2), na região sul do Brasil, utilizando microhistological análises de fezes. Foram identificadas 24 espécies de plantas nas amostras de fezes coletadas. Entre as espécies identificadas, nove são comuns a dieta dos animais de ambas as áreas, não sendo detectada a presença de Oriza sativa em nenhuma das amostras. Entre as espécies identificadas, 84\% e $54 \%$ da dieta do ratão-do-banhado, nas Áreas 1 e 2 respectivamente, são plantas aquáticas. A família Poaceae foi a mais abundante, sendo encontrada em $82 \%$ das amostras de ambas as áreas. Paspalum disthichum (Área 1) e Panicum tricholaenoides (Área 2), foram as espécies mais frequentes na dieta do ratão-do-banhado. A comparação da dieta de ambas as áreas mostrou que a alimentação varia dependendo do tipo de habitat, condições ambientais e de disponibilidade alimentar. A ausência de arroz na nossa análise pode ser um indicativo de que a preservação de áreas nativas ao redor de cursos d'água, evita que o ratão-do-banhado utilize as culturas de arroz.

Palavras-chave: ratão-do-banhado, dieta, seleção de alimento, herbivoria.

\section{REFERENCES}

ABBAS A. 1988. Impact du rangondin (Myocastor coypus Molina) sur une culture de mais (Zea mays L.) dans le marais Poitevin. Acta Oecol-Oec Appl 9(2): 173-189.

ABBAs A. 1991. Feeding strategy of coypu (Myocastor coypus) in central Western France. J Zool Lond 224: 385401.

BARRETO GR AND HERERA EA. 1998. Foraging patterns of capybaras in a seasonally flooded savanna of Venezuela. Zool Trop Ecol 14: 87-98.

BAUMgartner LL AND MARTIN AC. 1939. Planthistology as an aid in squirrel food habits. J Wildl Manage 3(3): $266-268$. 
BEST RC. 1981. Foods and feeding habits of wild and captive Sirenia. Mammal Review 11: 3-29.

Borges LV AND Colares IG. 2007. Feeding habits of capybaras (Hydrochoerus hydrochaeris, Linnaeus 1766), in the Ecological Reserve of Taim (ESEC-Taim) - South of Brazil. Brazil. Arch Biol Technol 50(3): 409-416.

Borgnia M, Galante ML and CAssini MH. 2000. Diet of the coypu (Nutria, Myocastor coypus) in agro-systems of Argentinean Pampas. J Wildl Manage 64(2): 354-361.

Borruel N, CAMPoS CM, GIANNONI SM AND BorGHI CE. 1998. Effect of herbivorous rodents (cavies and tuco-tucos) on a shurud community in the Monte Desert, Argentina. J Arid Environm 39: 33-37.

BRONSON FH. 1989. Mammalian reproductive biology. Chicago, The University of Chicago Press, 325 p.

Colares IG AND Colares EP. 2002. Food plants eaten by Amazonian manatees (Trichechus inunguis, Mammalia: Sirenia). Brazil. Arch Biol Technol 45: 67-72.

D’adAmo P, GUichón ML, Bó RF AND CASSINI MH. 2000. Habitat use by Myocastor coypus in agro-systems of the Argentinean Pampas. Acta Theriol 45: 25-33.

GALENDE GI AND GRIGERA D. 1998. Relaciones alimentárias de Lagidium viscacia (Rodentia, Chinchillidae) con herbívoros introducidos en el Parque Nacional Nahuel Huapi, Argentina. Iheringia, Ser Zool 84: 3-10.

Guichón ML, Benítez VB, ABbas A, Borgnia M And CASsini ML. 2003. Foraging behavior of coypus $M y$ ocastor coypus: why do coypus aquatic plants? Acta Oecol 24: 241-246.

IUCN. 2009. International Union for Conservation of Nature and Natural Resources. Red List. http//www.iucnredlist.org.

Kufner MB And Monge S. 1998. Dieta de Lagostomus maximus (Rodentia, Chinchillidae) en areas sometidas a intervención humana en el desierto del Monte, Argentina. Iheringia, Ser Zool 84: 175-184.
LEBRETON P. 1982. Tanins ou alcaloides: deux tactiques phytochimiques de dissuassion des herbivores. Rev Ecol Terre Vie 36: 539-572.

MCILROY RJ. 1964. An introduction to tropical grã sland husbandry. Oxford University Press, London, 128 p.

NogueirA-Neto P. 1993. Do Taim ao chui, da barra do Rio Grande as terras e águas do arroio Chui. SP: Empresa das Artes, 96 p.

Palomares F, Bó R, Beltrán JF, Villafañe G and MoREnO S. 1994. Winter circadian activity pattern of free-ranging coypus in the Paraná River Delta, eastern Argentina. Acta Theriol 39: 83-88.

Prigioni C, BAlestrieri A AND Remonti L. 2005. Food habits of the coypu, Myocastor coypus, and its impacto on aquatic vegetation in a freshwater habitat of NW Italy. Folia Zool 54(3): 269-277.

Quintana RD, Monge S AND Malvarez AI. 1994. Feeding-habits of capybara (Hydrochaeris hydrochaeris) in afforestation areas of the lower delta of the Parana River, Argentina. Mammalia 58(4): 569-580.

Ricklefs RE. 2003. A economia da natureza. 5a ed., Rio de Janeiro: Guanabara Koogan S.A. 503 p.

SAKAgUChi E AND NABATA A. 1992. Comparison of fibre digestion and digesta retention time between nutrias (Myocaster coypus) and guinea-pigs (Cavia porcellus). Comp Biochem Physiol 103A(3): 601-604.

SCHÄFER A. 1980. Critérios e métodos para a avaliação das águas superficiais - Análise de diversidade de biocenoses. NIDECO, Série Taim 1.

STORR GM. 1961. Microscopic analysis of faeces, a technique for ascertaining the diet of herbivorous mammals. Aust J Biol Sci 14: 157-166.

ZAR JH. 1984. Bioestatistical analysis. $2^{\text {nd }}$ ed., New Jersey: Prentice-Hall Inc. 718 p. 